\title{
Hydrology of the Lake Wingra Basin, Dane County, Wisconsin
}

100.

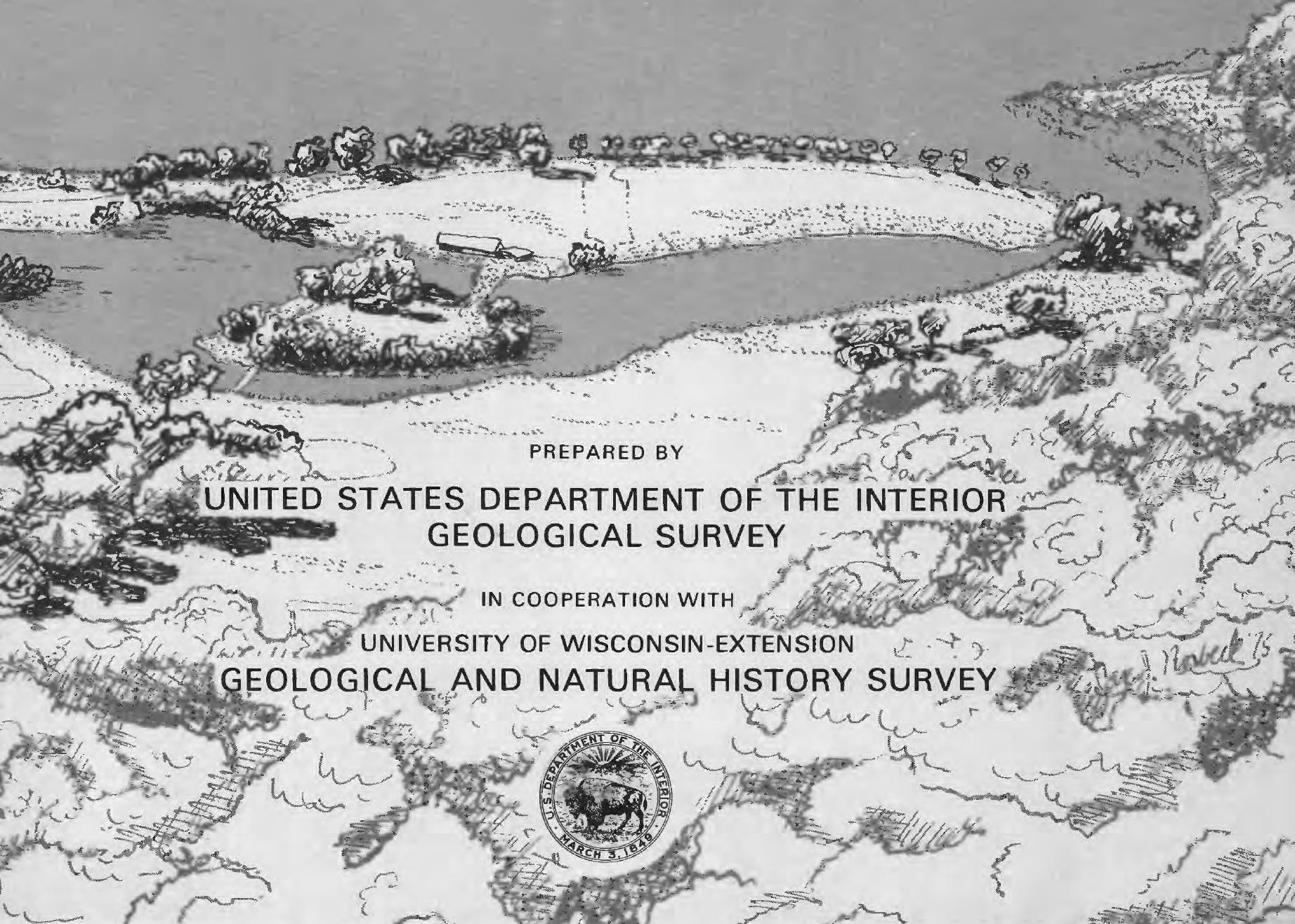


HYDROLOGY OF THE LAKE WINGRA BASIN, DANE COUNTY, WISCONSIN 7. Author(s)

E. L. Oakes, G. E. Hendrickson, and E. E. Zueh1s 9. Performing Organization Name and Address

U.S. Geological Survey

1815 University Avenue Madison, Wisconsin 53706

12. Sponsoring Organization Name and Address

U.S. Geological Survey

1815 University Avenue Madison, Wisconsin 53706

6.

8. Performing Organization Rept No. WRI $17-75$

10. Project/Task/Work Unit No.

15. Supplementary Notes

Prepared in cooperation with the University of Wisconsin-Extension, Geologica1 and Natural History Survey

16. Abstracts A water budget was prepared to identify the components of the hydrologic system in the Lake Wingra basin. The Lake Wingra basin, which includes a small eutrophic lake within the city of Madison, Wisconsin, is partly natural and partly urbanized. Measured and estimated inflow and outflow to and from the lake in one year (June 1972 to May 1973) was about 4.5 metres (15 feet)--approximately twice the volume of the lake. Lake gains are about 25 percent from precipitation on the lake surface, a from nearly equal amounts of surface runoff and ground-water inflow. Lake losses are about 10 percent ground-water outflow, 15 percent evaporation from the lake surface, a 75 percent discharge at the surface outlet. Increased pumpage from municipal and industrial wells in Madison has slowed the flow through the lake. The calculated 1972 water budget for the lake showed gains of about 356 centimetres ( 140 inches) and losse of about 350 centimetres (138 inches). A discrepancy of about 6 centimetres ( 2 inches probably was caused by uncertainties in ground-water inflow and outflow and by evapotranspiration and ground-water 1 flow in the narsh area southwst of the lake. 17. Key Words and Document Analysis. 17a. Descriptors

*Hydrologic budget, *Wisconsin, *Ground water, *Surface water

17b. Identifiers/Open-Ended Terms

*Lake Wingra

17c. COSATI Field/Group

18. Availability Statement

No restriction on distribution

19. Security Class (This Report) UNCLASSIEIED

20. Security Class (This Page UNCLASSIFIED

21. No. of Pages 37

22. Price 


\section{Hydrology of the Lake Wingra Basin, Dane County, Wisconsin}

E.L. Oakes, G.E. Hendrickson, and E.E. Zuehls

\section{U.S. GEOLOGICAL SURVEY}

Water-Resources Investigations 17-75

Prepared in cooperation with the

University of Wisconsin-Extension, Geological and Natural History Survey 


\title{
UNITED STATES DEPARTMENT OF THE INTERIOR Stanley K. Hathaway Secretary
}

\author{
GEOLOGICAL SURVEY \\ V.E. McKelvey Director
}

For additional information write to:

U.S. Geological Survey

1815 University Avenue

Madison, Wisconsin 53706 


\section{Contents}

Abstract-1-0

Introduction-10

Topography and geology

Surficial deposits-an 3

Bedrock-1.. 7

Acknowledgments - 7

Hydrologic system of the Lake Wingra basin- 7

Data network-10

Water budget for Lake Wingra basin- 15

Precipitation and evapotranspiration- 15

Ground water-a. 15

Surface water-- 17

Effects of ground-water withdrawal on surface water-_... 17

Water quality

Surface runoff-18

Ground water- 18

Lake water-

Water budget for Lake Wingra-

Precipitation- 22

Surface runoff-_at 22

Ground-water inflow- 23

Evaporation- 26

Lake Wingra outlet-1 27

Ground-water outflow- 27

Water budget--summary-- 28

Selected references

Illustrations

Figure 1-5. Maps showing:

1. Location of study area in Wisconsin-- 2

2. Surficial geology-n 4

3. Bedrock topography-a 5

4. Bedrock geology-no 6

5. Water table and ground-water movement-_... 9

Plate 1. Map showing hydrologic data sites in the Lake Wingra area, Dane County, Wisconsin 


\section{Tables}

Table 1. Generalized stratigraphy and aquifer system in the Lake Wingra area-.. 8

2. Meteorological data-collection sites-a 11

3. Surface-water recorder sites-a 12

4. Springflow data-collection sites-- 13

5. Ground-water data-collection sites-_. 14

6. Water budget for the Lake Wingra basin, 1972 16

7. Chemical analyses of samples of water from storm sewers and creeks

8. Discharge and specific conductance of water from Marshland Creek and storm sewers-( 20

9. Chemical analyses of samples of water from springs and a wel1-... 21

10. Monthly inflow and outflow and lake-stage changes for Lake Wingra, January 1972 through May 1973 24 


\section{Factors for Converting International System (SI) Units to English Units}

Divide SI units

$\begin{array}{lc}\text { millimetres }(\mathrm{mm}) & 25.4 \\ \text { metres }(\mathrm{m}) & .0254 \\ \text { metres }(\mathrm{m}) & .3048 \\ \text { kilometres }(\mathrm{km}) & 1.609 \\ \text { square kilometres }\left(\mathrm{km}^{2}\right) & 2.590 \\ \begin{array}{l}\text { litres }(1) \\ \text { litres per second }(1 / \mathrm{s})\end{array} & 3.785 \\ \text { kilograms (kg) } & .06309 \\ \text { cubic metres per second } & .4536 \\ \quad\left(\mathrm{~m}^{3} / \mathrm{s}\right) & \\ \text { cubic metres per day per } & .02832 \\ \quad \text { square metre }\left[\left(\mathrm{m}^{3} / \mathrm{d}\right) / \mathrm{m}^{2}\right] & \end{array}$

To obtain English units

inches (in)

inches (in)

feet (ft)

miles (mi)

square miles $\left(\mathrm{mi}^{2}\right)$

gallons (ga1)

gallons per minute

(gal/min)

pounds (1bs)

cubic feet per second $\left(\mathrm{ft} \mathrm{t}^{3} / \mathrm{s}\right)$

cubic feet per day per square foot $\left[\left(\mathrm{ft}^{3} / \mathrm{d}\right) /\right.$ $\mathrm{ft}^{2}$ ] 


\title{
Hydrology of the Lake Wingra Basin, Dane County, Wisconsin
}

\author{
E.L. Oakes, G.E. Hendrickson, and E.E. Zuehls
}

\section{Abstract}

A water budget was prepared to identify the components of the hydrologic system in the Lake Wingra basin. The Jake Wingra basin, which includes a sma11 eutrophic lake within the city of Madison, Wis., is partly a protected area and partly an urbanized area. Measured and estimated inflow and outflow to and from the lake in 1 year (June 1972 to May 1973) was about 4.5 metres (15 feet)--approximately twice the volume of the lake. Inflow to the lake is about 25 percent from direct precipitation on the lake surface, and the rest from nearly equal amounts of surface runoff and ground-water inflow. Outflow from the lake is about 10 percent ground-water outflow, 15 percent evaporation from the lake surface, and 75 percent discharge at the surface outlet. Increased withdrawal of water from municipal and industrial wells in Madison has slowed the rate of flow through the lake.

The calculated 1972 water budget for the lake showed gains of about 3,560 millimetres (140 inches) and losses of about 3,500 millimetres (138 inches). A discrepancy of about 60 millimetres (2 inches) probably was caused in part by uncertainties in ground-water inflow and outflow. Effects of evapotranspiration and ground-water inflow in the marsh area southwest of the lake also probably contribute to the discrepancy. 


\section{INTRODUCTION}

The Lake Wingra basin, within the city of Madison, Dane County, Wis., is a partly protected area and partly urbanized area. The basin (fig. 1) above the lake outlet includes a surface drainage area of $15.74 \mathrm{~km}^{2}$ $\left(6.07 \mathrm{mi}^{2}\right)$. This includes about 75 percent urban area--residential housing, businesses, schools, golf courses, cemeteries, and public parks--and about 25 percent University of Wisconsin Arboretum, an area of forest, prairie, and marsh.

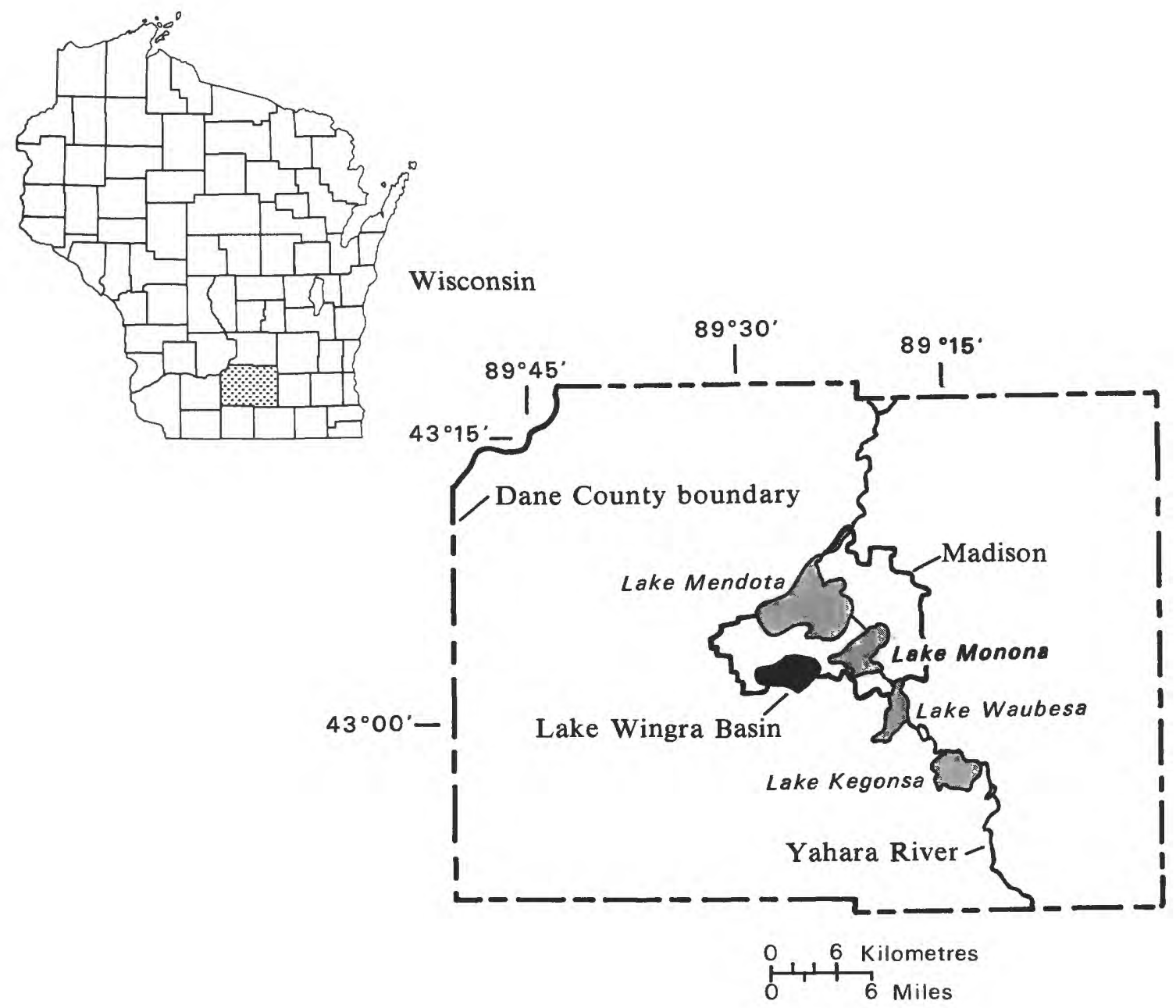

Figure 1. Location of study area in Wisconsin. 
Lake Wingra is near the south edge of the city of Madison at about $43^{\circ} 3^{\prime} \mathrm{N}$. 1atitude and $89024^{\prime} \mathrm{W}$. 1ongitude. It is a sma11 $1.37-\mathrm{km}^{2}\left(0.53-\mathrm{mi}^{2}\right)$ eutrophic lake. It is within the drainage of the Yahara River (fig. 1), which flows into the Rock River, a tributary of the Mississippi River.

The purpose of this report is to describe the hydrologic system in the Lake Wingra basin, with particular emphasis on the hydrologic budget of the lake itself. Support for this overall study was supplied, in part, by the Eastern Deciduous Forest Biome Project, IBP (International Biome Period), funded by the National Science Foundation under Interagency Agreement AG-199, 40-193-69, with the Atomic Energy Commission--Oak Ridge National Laboratory. The IBP funds for the work reported on here were included in the cooperative program with the University of Wisconsin-Extension, Geological and Natura1 History Survey and matched equally by the U.S. Geological Survey.

\section{Topography and Geology}

The Lake Wingra basin is in the Yahara River valley (fig. 1). The highest point in the drainage basin is $341 \mathrm{~m}(1,120 \mathrm{ft})$ above mean sea 1eve1; the lake is $258 \mathrm{~m}$ ( $848 \mathrm{ft}$ ) above sea level. The basin is composed chiefly of rolling uplands underlain by glacial moraines and outwash (fig. 2). Areas of low wetlands near the lake are underlain by peat, muck, and mar 1 .

Jake Wingra and related marsh deposits occupy a depression in thick deposits of sand, gravel, and silt. These deposits fill a bedrock valley (figs. 3 and 4), a tributary of the preglacial Yahara River.

\section{Surficial Deposits}

Glacial deposits in the Lake Wingra basin consist chiefly of morainal deposits that are largely till (fig. 2). Till is an unsorted, unstratified mixture of silt, clay, sand, grave1, cobbles, and boulders laid down directly by ice. Outwash deposits occur in upland areas of the Lake Wingra basin south and southwest of the lake. Outwash is a sorted water-laid deposit of stratified material, chiefly sand and gravel, deposited by glacial streams. The glacial deposits are thickest, generally around $30-45 \mathrm{~m}(100-150 \mathrm{ft})$, in a bedrock valley (fig. 3) trending generally northeast along the orientation of Jake Wingra.

Surficial marsh deposits, outwash and alluvium, cover these morainal deposits over part of the basin. A few small areas of stratified lake deposits of marl, sand, and silt are included in the areas mapped as outwash. Marsh deposits occupy the margins of Lake Wingra on the southwest, south, and southeast. Auger holes through these marsh deposits show only a few feet of organic material overlying 4-24 m (10-60 ft) of lake clay and marl. Beneath the clay, 2-16 m (6-40 ft) of silty sand overlies a few feet of sandy till, which rests on bedrock. 


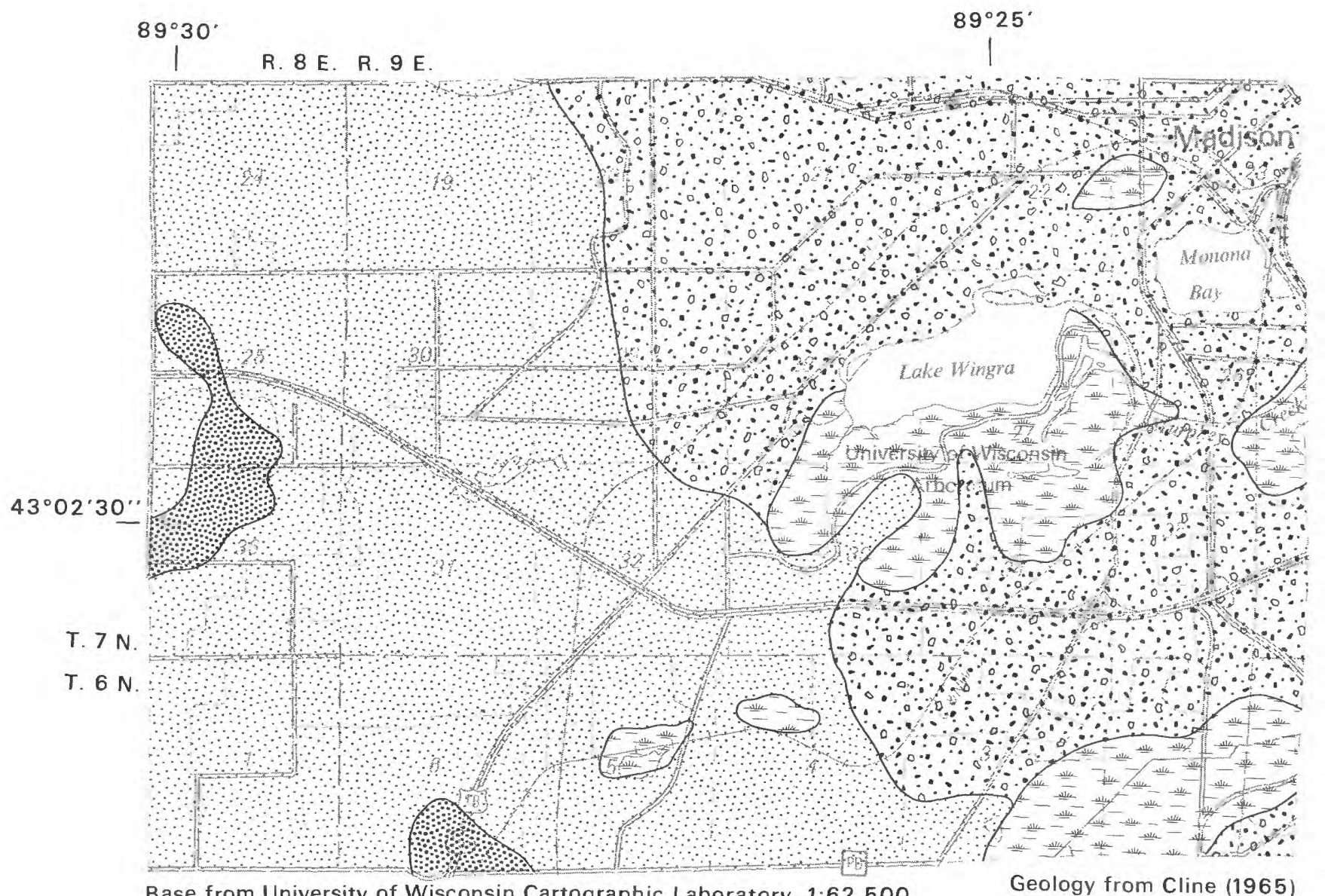

Base from University of Wisconsin Cartographic Laboratory, 1:62,500

Geology from Cline (1965)

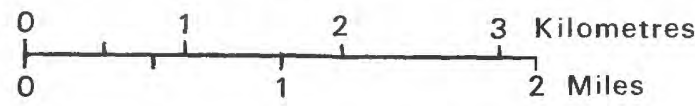

\section{EXPLANATION}

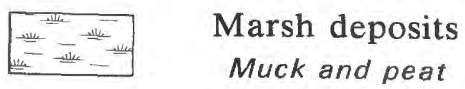

Muck and peat

Morainal deposits

Clay, silt, sand, gravel, and boulders, mostly unsorted and unstratified
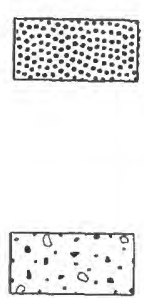

Outwash and alluvium

Mostly sand and gravel, sorted and stratified

Undifferentiated glacial deposits mainly ground moraine

Clay, silt, sand, gravel, and boulders, unstratified to stratified, unsorted to sorted

Contact

Figure 2. Surficial geology. 


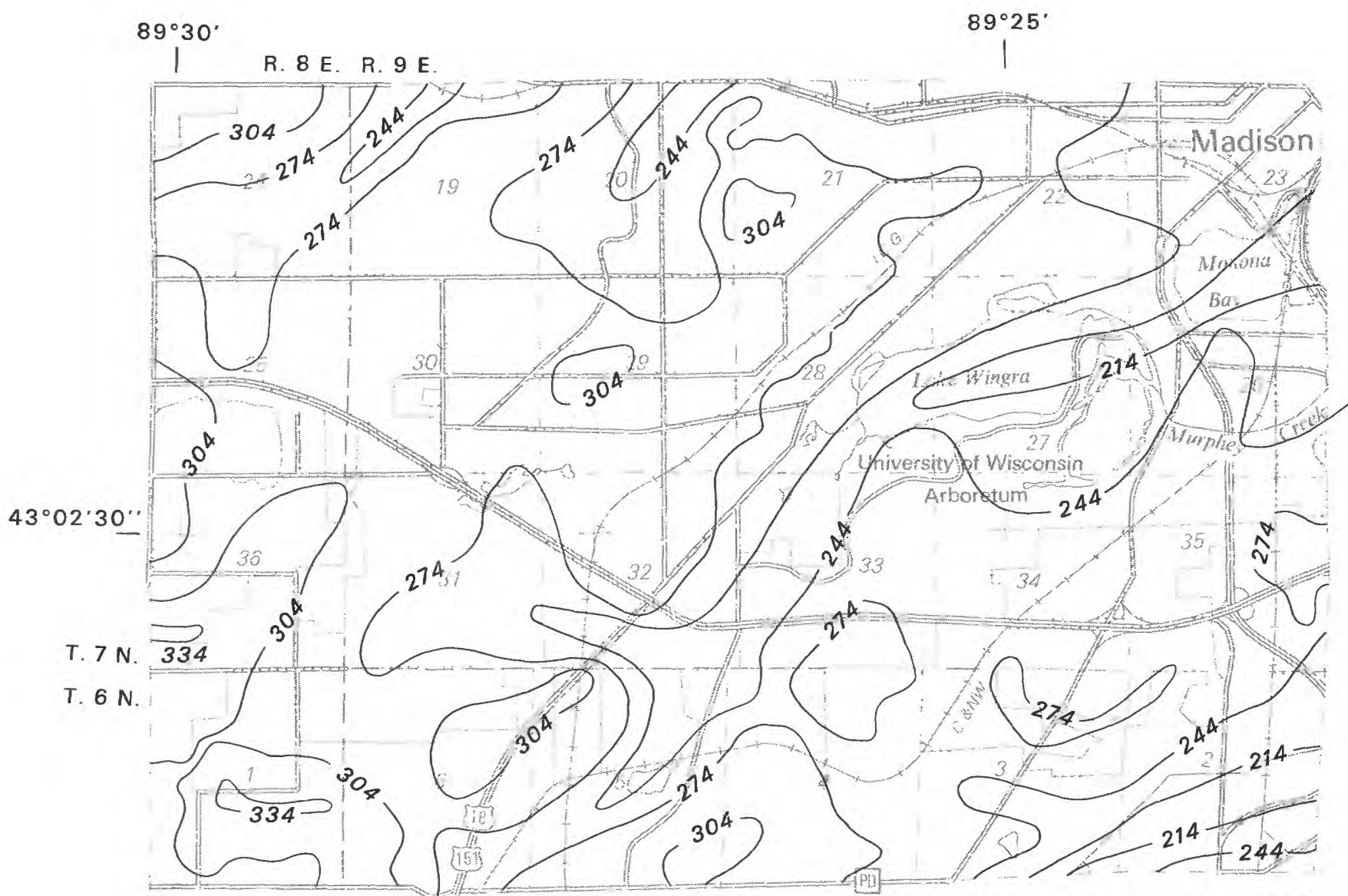

Base from University of Wisconsin Cartographic Laboratory,

Bedrock topography from Cline (1965) $1: 62,500$

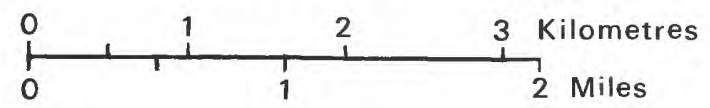

EXPLANATION

\section{Bedrock contour}

274 Shows altitude of bedrock surface. Contour interval 30 metres (100 feet). Datum is mean sea level

Figure 3. Bedrock topography. 


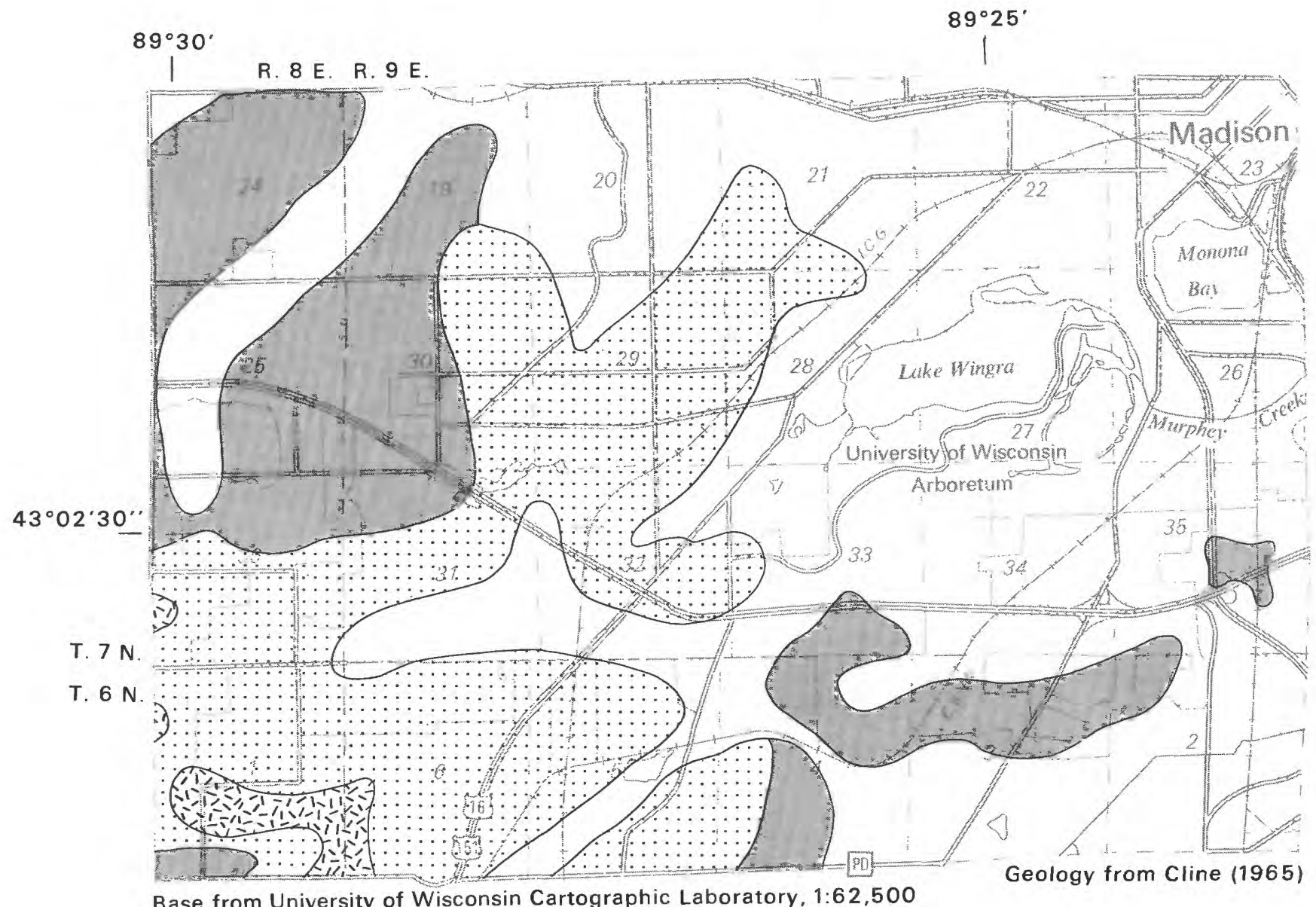

Base from University of Wisconsin Cartographic Laboratory, 1:62,500

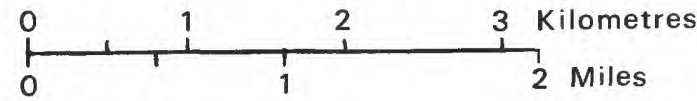

\section{EXPLANATION}

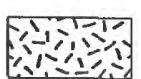

Galena Dolomite. Decorah

Formation, and Platteville Formation, undifferentiated

$\because: 3:: \quad$ St. Peter Sandstone

Prairie du Chien Group

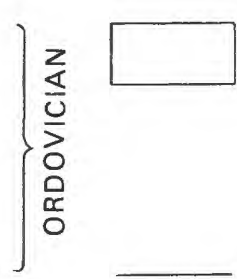

Trempealeau Formation, Franconia

Sandstone, Galesville Sandstone,

Eau Claire Sandstone, and Mount

Simon Sandstone, undifferentiated

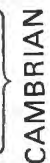

Contact

Figure 4. Bedrock geology. 
A layered sequence of sedimentary rock underlies the glacial deposits in the basin. These sedimentary rocks are mainly sandstone and dolomite and range in age from Cambrian to Ordovician (table 1). In the basin they dip gently to the south and southeast.

These rocks, particularly the sandstone, are permeable and saturated and are the principal source of water for the Madison area.

The geologic column in the Lake Wingra area is shown on table 1 . The Cambrian rocks, which include several sandstones with some dolomite and shale, are as much as $271 \mathrm{~m}$ (890 ft) thick in the basin. Overlying the Cambrian rocks, the Prairie du Chien Group may be as thick as $23 \mathrm{~m}$ (75 ft). In this basin the St. Peter Sandstone is as much as $38 \mathrm{~m}$ (125 ft) thick. Dolomite of the Platteville and Decorah Formations and Galena Dolomite overlie the St. Peter Sandstone to the south but are not present in the Lake Wingra basin. Total thickness of the sedimentary rocks is about $244-274 \mathrm{~m}$ (800-900 ft).

\section{Acknowledgments}

Work on this project was assisted greatly by the contributions of many agencies and individuals. We11 logs were supplied by the University of Wisconsin-Extension, Geological and Natural History Survey, and the Wisconsin Department of Natural Resources. Municipal pumpage records were supplied by the city of Madison Water Utility. Evaporation data and other information were furnished by the Lake Wingra Study Office of the University of Wisconsin. Permission for the installation of observation wells was granted by the University of Wisconsin Arboretum Committee and the Nakoma Country Club. Permission for the installation of storm-sewer gages was granted by the city of Madison's Street Department. The authors of this report grateful1y acknow1edge a11 of the above assistance. The authors also wish to thank the land and we11 owners for supplying data on wells and allowing access to sites for the installation of observation wells and rain gages.

\section{HYDROLOGIC SYSTEM OF THE LAKE WINGRA BASIN}

The divides that shape the ground-water and the surface-water drainage areas of the Lake Wingra basin differ significantly (fig. 5). The groundwater divide is indistinct and subject to interpretation in the western part of the basin. Near Lake Wingra and Madison, its configuration is altered by the combined effects of recharge and discharge of ground water, including discharge through we11s. The surface-water divide differs from the topographic divide because of modification by storm sewers. Both divides are subject to further changes brought about by further urban development. In this report the Lake Ningra basin is considered to be that defined by the surface-water divide, except that ground-water inflow and outflow are computed on the basis of the boundaries of the ground-water basin. 


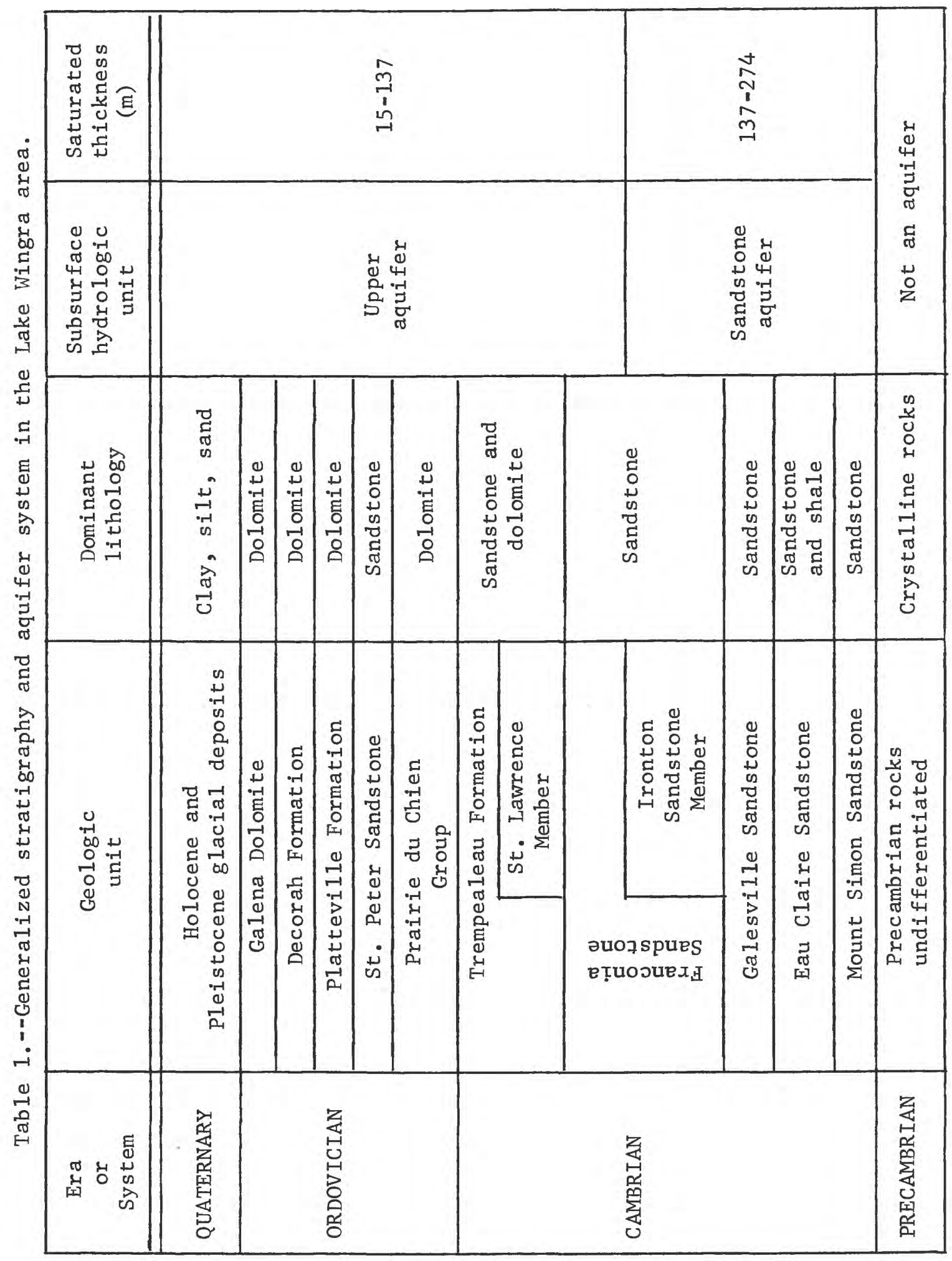




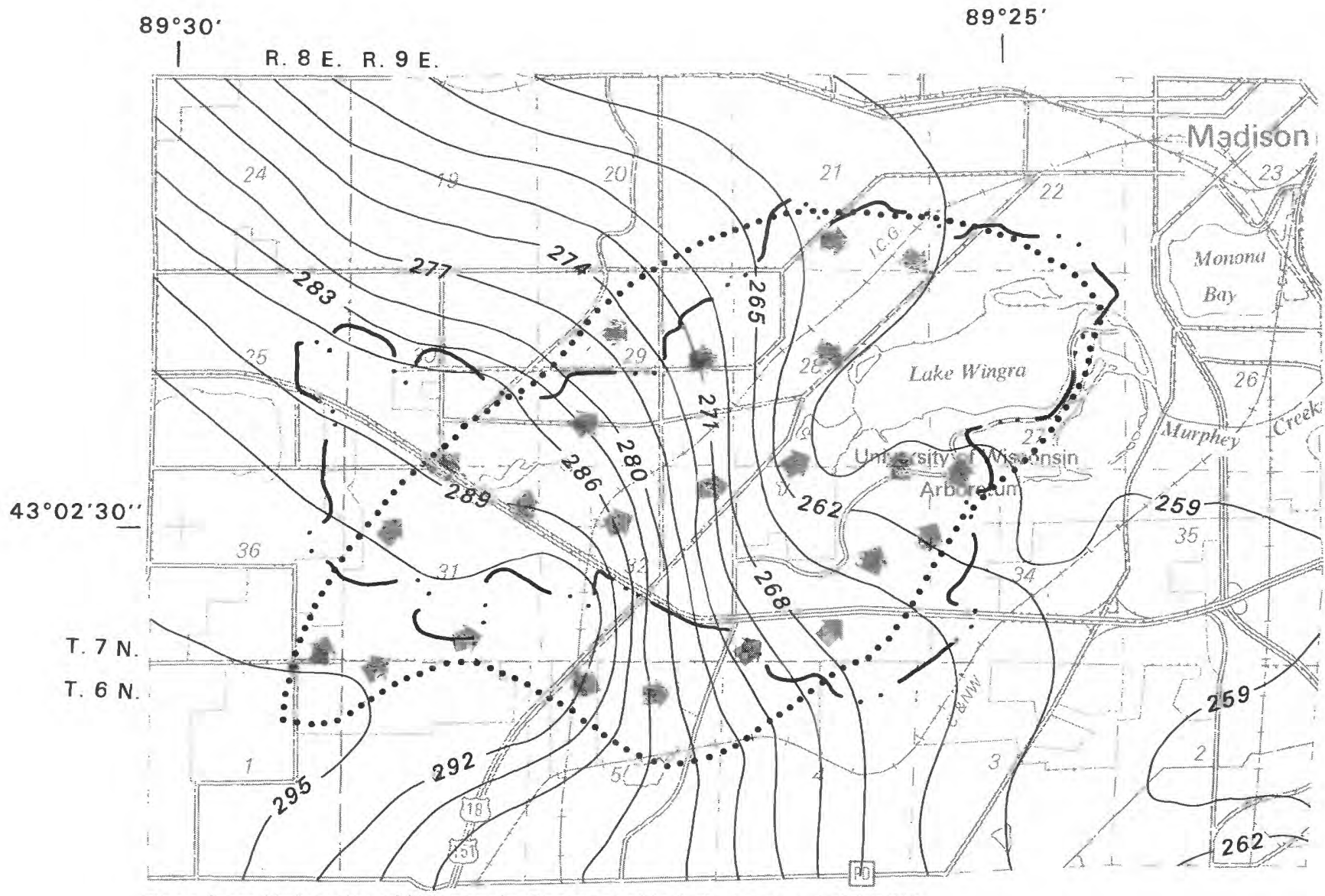

Base from University of Wisconsin Cartographic Laboratory, 1:62,500

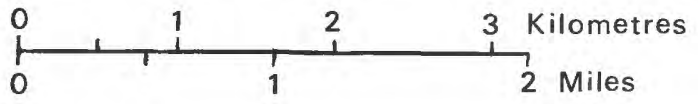

EXPLANATION

Water-table contour

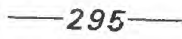

Shows altitude of water table during September 1973. Contour interval 3 metres (10 feet). Datum is mean sea level

I. Direction of ground-water flow
- - Surface-water divide, as defined by storm sewers

Ground-water divide

Figure 5. Water table and ground-water movement. 
Pumpage by Madison's deep wells from the sandstone aquifer has modified artesian pressures in the Lake Wingra area. This subject has been covered in detail by McLeod (1975).

\section{Data Network}

The Lake Wingra basin receives and loses water through natural and maninduced processes. Nater income is by direct precipitation and by groundwater underflow. Water loss is by evaporation, transpiration, surface runoff, ground-water underflow, and by withdrawal of water from wells. All of these factors must be accurately accounted for to make practical estimates of the water budget.

To monitor components of the hydrologic system in the Lake Wingra basin, a network of data-collection stations was established (tables 2-51/, p1. 1). The discharge of streams, storm sewers, and springs was gaged to define inflow to the lake. Water-level fluctuations in observation wells defined changes in ground-water storage and ground-water movement.

Precipitation was measured at seven locations in or near the Lake Wingra basin (table 2). Two gages were recording gages used during the entire year, and a third recording gage was used from May through October. Four standard rain gages completed the network. An evaporation pan was maintained from April to October each year.

Surface-runoff data were collected at three stream gages and five stormsewer gages (table 3). Runoff normally occurred only during and immediately after significant rainfall or snowmelt. Therefore, during much of the time there was no discharge. Marshland Creek, a tributary to Jake Wingra, also flowed intermittently. A continuous-recording gage was maintained on this stream. A gage on the Lake Wingra outlet measured discharge from the lake to Murphy Creek. A gage on Murphy Creek, at Beld Street about $1.6 \mathrm{~km}$ (1 mi) below the Lake Wingra outlet, measured the lake-outlet flow plus flow from the additional drainage area and seepage or overland flow out of the lake. Five storm-sewer gages collected runoff data from urbanized areas in the Lake Wingra basin. Records from a lake-stage gage on Lake Monona were used in computation of flow records at the Beld Street gage during periods when high stages of Lake Monona caused backwater conditions. The stage of Lake Wingra was continuously monitored at the lake outlet. The stage of Lake Monona also was continuously monitored.

Discharges from three springs were monitored year-round (table 4). Five additional springs were monitored from April to August 1973.

1/A two-part system of letters and numbers is used to designate we11s and springs in this report. The first part, Dn, is the county abbreviation. The second part is the serial number, assigned in the order that the well or spring was inventoried in the county. Springs are distinguished from wells by the letters "sp" following the serial number. 


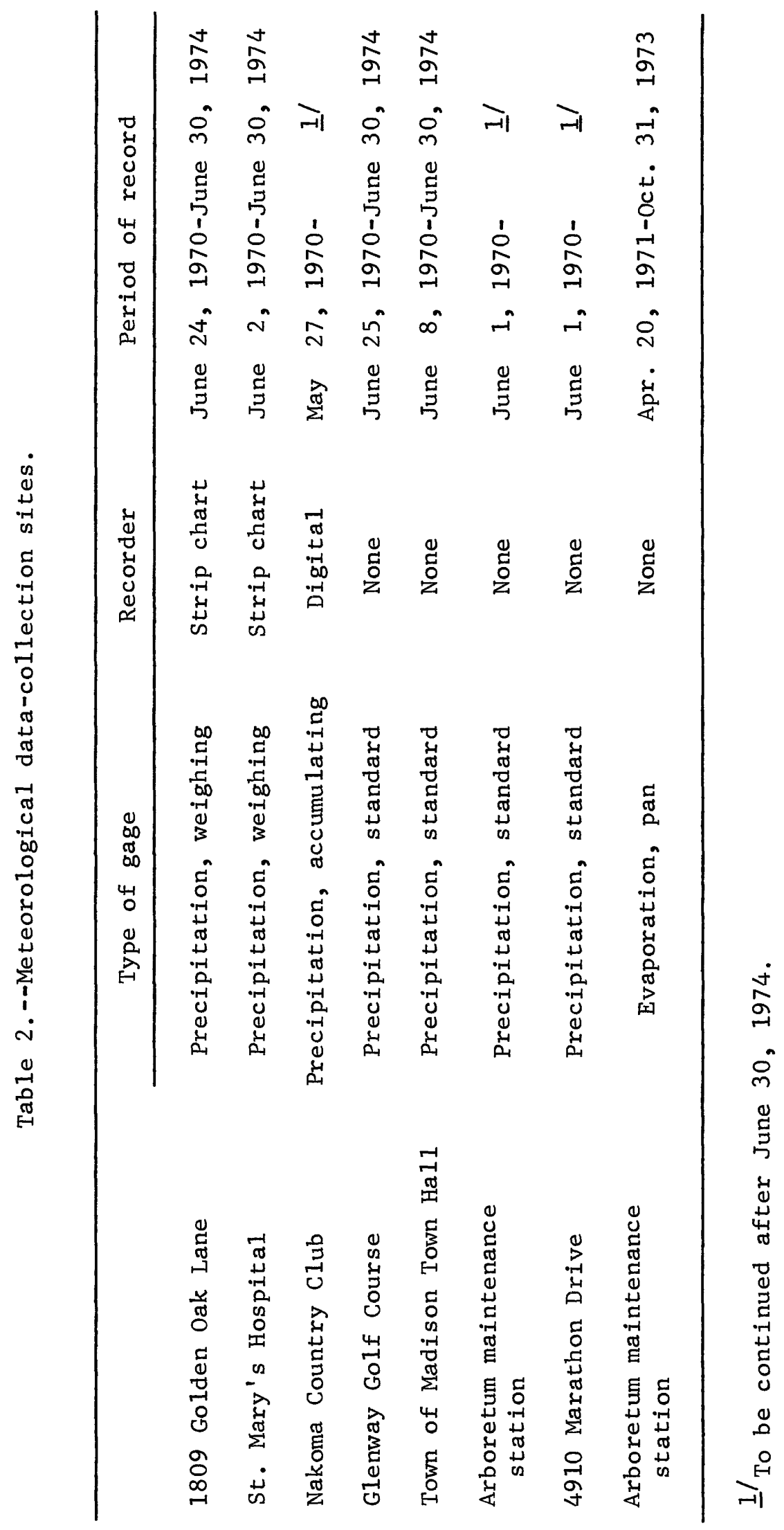




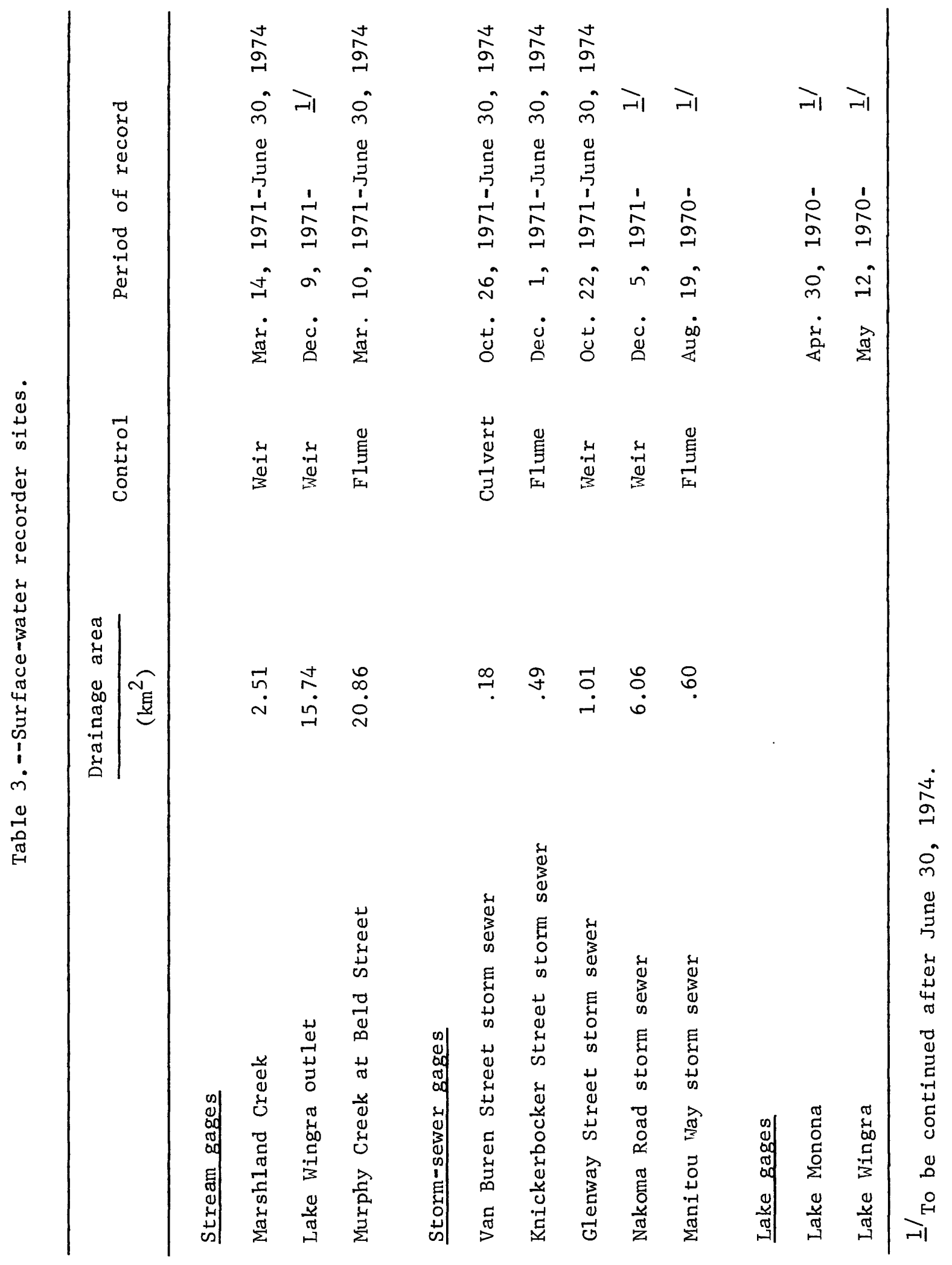




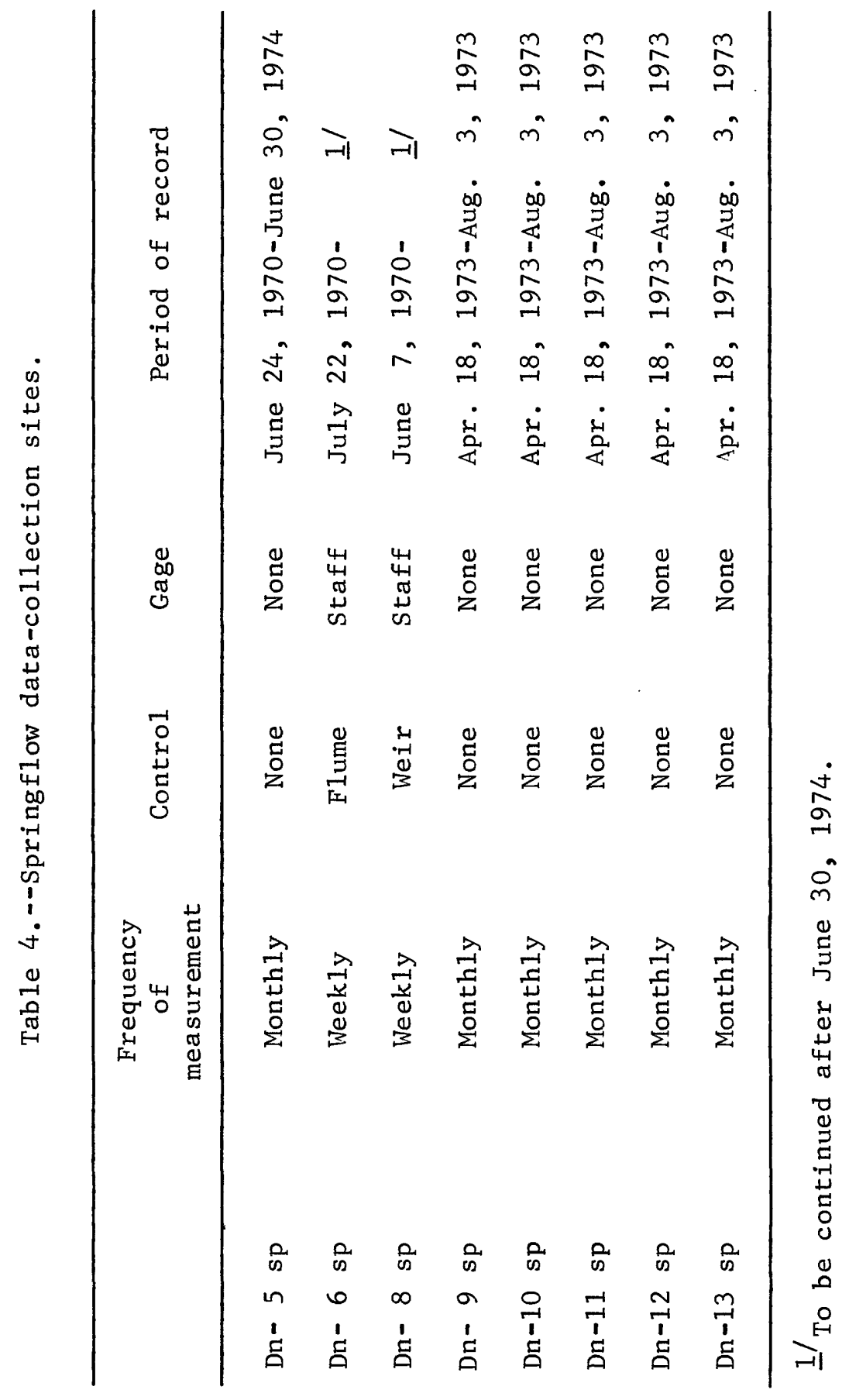




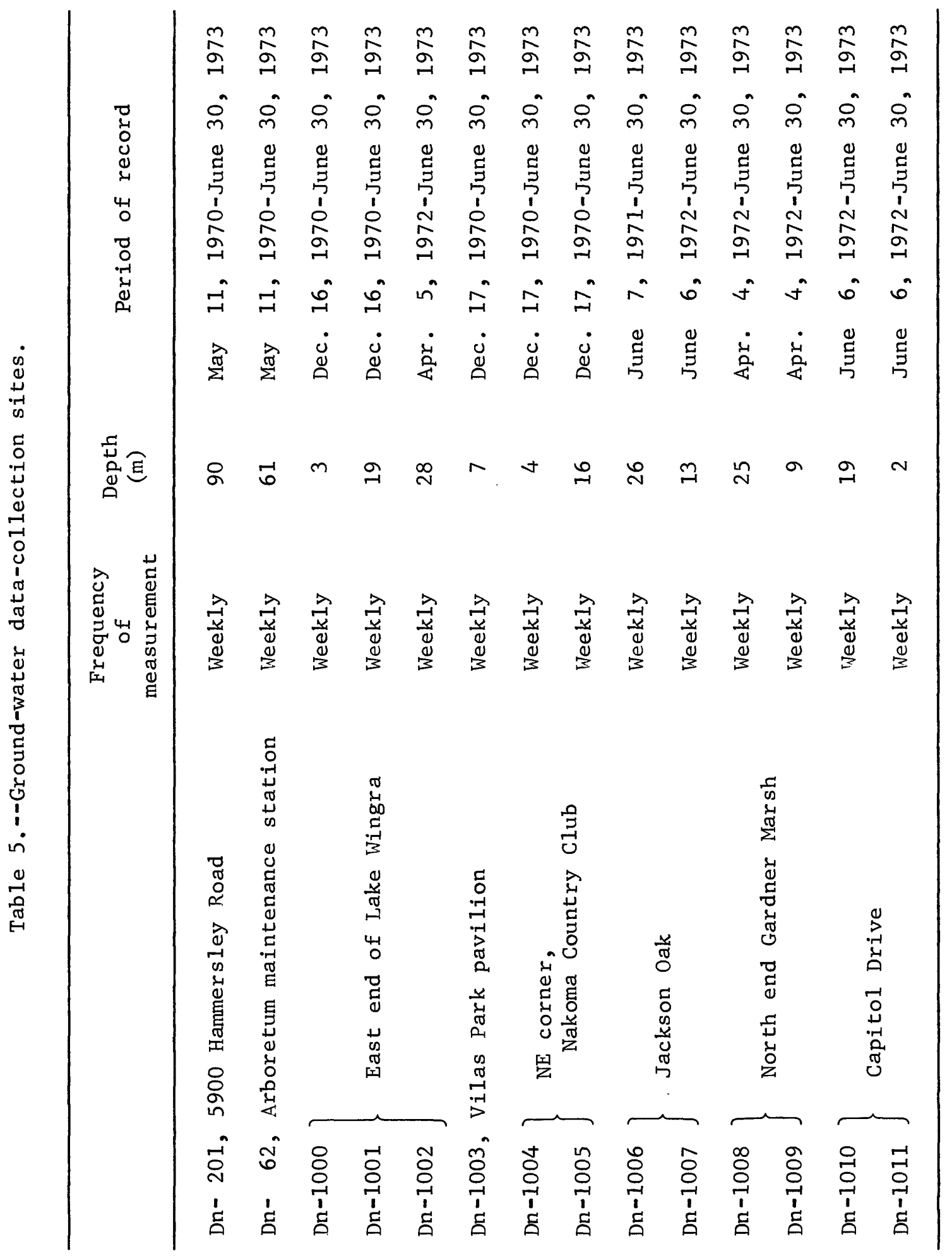


Water-level fluctuations in bedrock aquifers were monitored at two sites (table 5). Water-level fluctuations in the unconsolidated material above the bedrock were measured at six sites. Grouped we1ls, one relatively shallow and one or more deep, were measured at five of the six sites to determine potential for vertical movement of water in the glacial drift.

\section{Water Budget for Lake Wingra Basin}

A water budget was prepared for the Lake Wingra basin to quantify water movement (table 6). This budget also serves as a framework for the more detailed budget of the lake itself. Measured quantities in the budget are precipitation, surface runoff to and from Lake Wingra, and ground-water discharge to Jake Wingra in visible springs and seeps. A11 other quantities are estimated.

The following discussion is based chiefly on records for the 1972 calendar year. This was the first full year that hydrologic instrumentation was virtually complete.

\section{Precipitation and Evapotranspiration}

In 1972 precipitation on the Lake Wingra basin was about $760 \mathrm{~mm}$ (29.9 in), which is about the average annual precipitation for the Madison area. This is equivalent to an average rate of about $0.38 \mathrm{~m}^{3} / \mathrm{s}\left(13.4 \mathrm{ft}^{3} / \mathrm{s}\right)$.

Evaporation from Jake Wingra computed by D. D. Huff (written commun., 1973) was $650 \mathrm{~mm}$ (25.6 in), equivalent to a loss of $60 \mathrm{~mm}$ (2.4 in) distributed evenly over the entire basin. The evaporation loss was at an average rate of $0.03 \mathrm{~m}^{3} / \mathrm{s}\left(1.1 \mathrm{ft}^{3} / \mathrm{s}\right)$.

Evapotranspiration from the land area of the basin was about $470 \mathrm{~mm}$ (18.5 in), equivalent to a loss of $430 \mathrm{~mm}$ (16.9 in) distributed evenly over the entire basin. The evapotranspiration loss was at an average rate of $0.21 \mathrm{~m}^{3} / \mathrm{s}\left(7.4 \mathrm{ft}^{3} / \mathrm{s}\right)$. Evapotranspiration was estimated to be the residual water loss from the basin after measurement and computation of all other losses.

The combined evapotranspiration losses from the lake and from the land area equal $490 \mathrm{~mm}(19.3 \mathrm{in})$, or a loss rate of $0.24 \mathrm{~m}^{3} / \mathrm{s}\left(8.5 \mathrm{ft}^{3} / \mathrm{s}\right)$.

\section{Ground Water}

Recharge to shallow aquifers in the Lake Wingra basin occurs chiefly in the upland areas west and southwest of the lake. Ground water moves generally east and northeast toward the lake. Movement of ground water in the Lake Wingra area is complex because of the response of the sandstone aquifer to large withdrawals of water for municipal and industrial uses. R. S. McLeod (1975) assumed two major aquifers, each having a discrete potentiometric surface in the Madison area. The lower aquifer, termed the "sandstone aquifer", includes the Ironton Sandstone Member of the Franconia Sandstone 
Table 6.--Water budget for the Lake Wingra basin, 1972 .

Annual amount

for basin area

(mm)
Average rate

of flow

$\left(\mathrm{m}^{3} / \mathrm{s}\right)$

Gain:

Precipitation on land area

690

0.35

Precipitation on lake area

70

.03

Ground-water inflow from

outside basin

Total gain

$\frac{20}{780}$

Loss :

Evapotranspiration from

land area

430

.21

Evaporation from lake area

60

.03

Surface discharge from basin

(at lake outlet)

210

.11

Ground-water outflow from

basin

Total loss

and all underlying Cambrian sandstones (table 1). The upper aquifer includes the glacial drift and all bedrock formations overlying the Ironton Sandstone Member. Most high-capacity municipal and industrial wells withdraw water from the sandstone aquifer. Most domestic wells obtain water from the upper aquifer. Water levels used to define the ground-water basin discharging to Lake Wingra (fig. 5) were from wells in the upper aquifer.

Movement of water in the sandstone aquifer is strongly influenced by withdrawal of water from municipal and industrial wells. Movement of water in the upper aquifer also is influenced by this withdrawal, but the influence is less because the low permeability of the stratum at the base of the St. Lawrence Member of the Trempealeau Formation (table 1) inhibits vertical movement of water. Five of the springs discharging into Lake Wingra emerge from the St. Lawrence Mmber near its base. The low permeability of this member lessens but does not eliminate the influence of withdrawals of water from municipal wells on the springs. Discharge of springs Dn-9 and $10 \mathrm{sp}$ declined from about $12 \mathrm{l} / \mathrm{s}$ (190 gal/min) to $9 \mathrm{l} / \mathrm{s}$ (143 gal/min) after a nearby city wel1 (Dn-46) (p1. 1) was pumped for 2 days at a rate of about $60 \mathrm{l} / \mathrm{s}$ (951 gal/min). Discharge of spring Dn-6 sp, about one-quarter mile farther from the pumping we11, was not noticeably affected. 
Annual recharge to the upper aquifer in the Lake Wingra basin, including about $20 \mathrm{~mm}$ (0.8 in) of ground-water inflow from outside the basin, is estimated to average ${ }_{3}$ about $200 \mathrm{~mm}(8.0 \mathrm{in})$. This is equivalent to an average rate of about $0.10 \mathrm{~m} / \mathrm{s}\left(3.5 \mathrm{ft}^{3} / \mathrm{s}\right)$. In 1972 recharge was estimated to be $240 \mathrm{~mm}(9.4 \mathrm{in})$, and about $110 \mathrm{~mm}$ or $4.3 \mathrm{in}\left(0.05 \mathrm{~m}^{3} / \mathrm{s}\right.$ or $\left.1.8 \mathrm{ft}^{3} / \mathrm{s}\right)$ of this was discharged to Lake Wingra as visible springs and seeps; $30 \mathrm{~mm}$ or 1.2 in $\left(0.014 \mathrm{~m}^{3} / \mathrm{s}\right.$ or $0.5 \mathrm{ft}^{3} / \mathrm{s}$ ) reached the sandstone aquifer. (It is estimated that about half the recharge from the upper aquifer to the sandstone aquifer comes from the thick glacial deposits in the buried bedrock valley beneath Lake Wingra.) About $20 \mathrm{~mm}$ or $0.8 \mathrm{in}\left(0.01 \mathrm{~m}^{3} / \mathrm{s}\right.$ or $\left.0.4 \mathrm{ft}^{3} / \mathrm{s}\right)$ is estimated to be lost from the upper aquifer by evapotranspiration (p. 16) from the marshland near the southwest end of the lake.

\section{Surface Water}

Surface runoff in the Lake Wingra basin is chiefly in storm sewers and intermittent streams. The only perennial streams in the basin other than the lake outlet are those leading from springs to the lake. In this report, storm sewer names are those used by W. E. Noland (1951).

In 1972 discharge of the storm sewers and intermittent streams to Lake Wingra was about $100 \mathrm{~mm}$ or 3.9 in $\left(0.048 \mathrm{~m}^{3} / \mathrm{s}\right.$ or $\left.1,7 \mathrm{ft}^{3} / \mathrm{s}\right)$. Discharge at the lake outlet was about $210 \mathrm{~mm}$ or 8.3 in $\left(0.11 \mathrm{~m}^{3} / \mathrm{s}\right.$ or $\left.3.9 \mathrm{ft}^{3} / \mathrm{s}\right)$. The greater discharge at the lake outlet $(110 \mathrm{~mm}$ or $4.3 \mathrm{in}$ greater) represents the balance between additions to the lake from ground water (including spring discharge) and by precipitation on the lake surface, and losses from the lake by ground-water outflow and by evaporation from the lake surface. Differences in the balance of water entering and leaving the lake are reflected in changes in water stored in the lake. In 1972 the lake level was the same at the end of the year as in the beginning, so there was no net change in storage that year.

\section{Effects of Ground-Water Withdrawal on Surface Water}

Before the development of municipal-supply wells in Madison, Lake Wingra undoubtedly received ground-water discharge from both the upper and the sandstone aquifers. Withdrawal of water from municipal and industrial wells eliminated discharge to the lake from the sandstone aquifer and induced recharge from the upper aquifer to the sandstone aquifer, thereby reducing the discharge from the upper aquifer to the lake. Withdrawals of water increased from less than $4,000 \mathrm{~m}^{3} / \mathrm{d}\left(140,000 \mathrm{ft}^{3} / \mathrm{d}\right)$ in 1882 to about $120,000 \mathrm{~m}^{3} / \mathrm{d}\left(4,200,000 \mathrm{ft}^{3} / \mathrm{d}\right)$ in 1970 (R. S. McLeod, 1975). This 30-fold increase in water withdrawals from the lower sandstone aquifer resulted in flow changes between the upper and the sandstone aquifers. R. S. McLeod (1975) computed these flow changes by means of a digital model of the aquifer system in the Madison area. The change in flow rates in the Lake vingra area by 1970 resulted in increased recharge from the upper aquifer to the sandstone aquifer ranging from about $15 \mathrm{~mm}(0.6 \mathrm{in})$ of water in the western part of the basin to about $460 \mathrm{~mm}$ (18 in) in the eastern part that year. The average annual increase of recharge from the upper to the sandstone aquifer in the Lake Wingra basin is estimated to be $80 \mathrm{~mm}$ ( $3 \mathrm{in}$ ). 
The decreased ground-water discharge to the lake caused by pumping from the sandstone aquifer results in a lower rate of flow through the lake ( $\mathrm{Cline}$, 1965, p. 61), so the time required to flush the lake is greater. The volume of water moving into and out of Lake Wingra annually is about twice the total volume of the lake. Before the large withdrawals of water from the sandstone aquifer, the volume of water moving through the lake in 1 year must have been even greater.

\section{Water Quality}

The quality of water in Lake Wingra depends on the quality of water in the several sources entering the lake and on chemical changes taking place in the lake. Water discharged at the lake outlet is generally representative of the quality of the lake, except during periods of rapid runoff, when mixing may be incomplete.

\section{Surface Runoff}

The water entering Lake Wingra through storm drains and Marshland Creek probably is of the calcium magnesium bicarbonate type except during periods of snowmelt, when road salt adds large quantities of sodium and chloride to the runoff (table 7). Specific conductance, an indicator of the concentration of dissolved solids, was measured periodically. It ranged from 180 to 850 micromhos in 10 samples of water from Marshland Creek, and from 80 to 5,000 micromhos in 8 samples from 2 storm sewers (table 8). The variation in quality of the surface runoff is due, in part, to variations in discharge, but the extremely high values occur at times of snowmelt and are attributed to road salt.

\section{Ground Water}

The water discharged by springs to Lake Wingra is of the calcium bicarbonate type and is much more uniform in quality than the surface runoff. Chemical analyses of representative samples of water from the springs are 1isted in table 9. Kluesener (1972, p. 196-202) lists analyses of samples from four of the springs collected about twice monthly from January 1970 through April 1971. Specific conductance and calcium concentration of these samples are summarized below:

\begin{tabular}{|c|c|c|c|c|c|c|}
\hline \multirow{2}{*}{$\begin{array}{l}\text { Spring } \\
\text { number }\end{array}$} & \multicolumn{3}{|c|}{$\begin{array}{l}\text { Specific conductance } \\
\text { (micromhos) }\end{array}$} & \multicolumn{3}{|c|}{$\begin{array}{r}\text { Calcium }\left(\mathrm{Ca}^{++}\right) \\
\text {(milligrams per 1itr } \\
\end{array}$} \\
\hline & Max & Min & Mean & Max & Min & Mean \\
\hline $\mathrm{Dn}-5 \mathrm{sp}$ & 620 & 540 & 580 & 84 & 61 & 77 \\
\hline $\mathrm{Dn}-6 \mathrm{sp}$ & 760 & 645 & 690 & 95 & 71 & 88 \\
\hline $\mathrm{Dn}-9 \mathrm{sp}$ & 920 & 640 & 735 & 103 & 80 & 90 \\
\hline $\mathrm{Dn}-12 \mathrm{sp}$ & 640 & 540 & 580 & 87 & 53 & 79 \\
\hline
\end{tabular}


Table 7.--Chemical analyses of samples of water from storm sewers and creeks. [Analyses in milligrams per litre except specific conductance and $\mathrm{pH}$, in standard units.]

\begin{tabular}{|c|c|c|c|c|c|c|c|}
\hline & 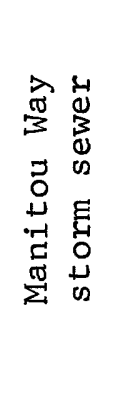 & 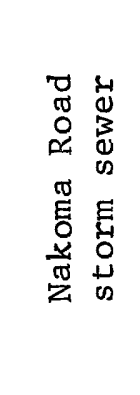 & 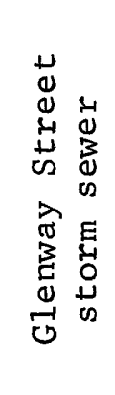 & 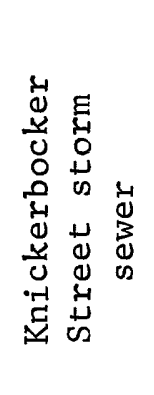 & 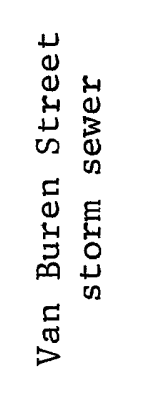 & 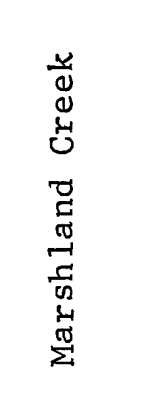 & 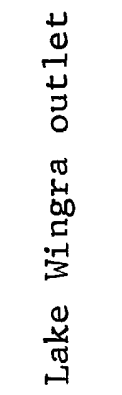 \\
\hline $\begin{array}{l}\text { Date collected } \\
\qquad(1973)\end{array}$ & $8-23$ & $8-23$ & $8-23$ & $8-23$ & $8-23$ & $4-18$ & $4-18$ \\
\hline Calcium (Ca) & 11 & 9.4 & 8.5 & 7.4 & 8.6 & 65 & 54 \\
\hline Magnesium (Mg) & 3.7 & 3.4 & 2.6 & 2.2 & 3.1 & 6.8 & 25 \\
\hline Sodium (Na) & 7.8 & 7.3 & 5.4 & 2.6 & 6.0 & 95 & 38 \\
\hline Potassium (K) & 3.1 & 2.7 & 2.4 & 3.5 & 4.5 & 3.1 & 2.8 \\
\hline $\begin{array}{l}\text { Bicarbonate } \\
\quad\left(\mathrm{HCO}_{3}\right)\end{array}$ & 46 & 40 & 35 & 28 & 38 & 136 & 170 \\
\hline $\begin{array}{l}\text { Carbonate } \\
\qquad\left(\mathrm{CO}_{3}\right)\end{array}$ & 0 & 0 & 0 & 0 & 0 & 0 & 0 \\
\hline Sulfate $\left(\mathrm{SO}_{4}\right)$ & 11 & 9.0 & 10 & 9.2 & 11 & 15 & 71 \\
\hline Chloride (C1) & 9.2 & 6.8 & 3.9 & 2.0 & 5.8 & 190 & 76 \\
\hline Fluoride (F) & .1 & .1 & .1 & .1 & .1 & .5 & .2 \\
\hline Nitrate $\left(\mathrm{NO}_{3}\right)$ & 2.7 & 4.4 & 3.4 & 3.4 & 3.1 & .2 & 2.6 \\
\hline $\begin{array}{l}\text { Dissolved } \\
\text { solids }\end{array}$ & 77 & 70 & 52 & 46 & 71 & 463 & 327 \\
\hline $\mathrm{Hard}-\mathrm{CaCO}_{3}$ & 42 & 38 & 32 & 28 & 34 & 190 & 239 \\
\hline $\begin{array}{ll}\text { ness } & \text { Noncar- } \\
\text { bonate }\end{array}$ & 5 & 4 & 4 & 4 & 4 & 78 & 99 \\
\hline $\begin{array}{c}\text { Specific } \\
\text { conductance }\end{array}$ & 131 & 115 & 96 & 79 & 111 & 820 & 574 \\
\hline $\mathrm{pH}$ & 6.7 & 6.8 & 6.6 & 6.5 & 6.5 & 7.5 & 7.5 \\
\hline
\end{tabular}


Table 8.--Discharge and specific conductance of water from Marsh1and Creek and storm sewers.

\begin{tabular}{|c|c|c|}
\hline Date collected & $\begin{array}{c}\text { Discharge } \\
\left(\mathrm{m}^{3} / \mathrm{s}\right)\end{array}$ & $\begin{array}{l}\text { Specific } \\
\text { conductance } \\
\text { (micromhos) }\end{array}$ \\
\hline \multicolumn{3}{|c|}{ Marshland Creek } \\
\hline $\begin{array}{l}\text { Mar. 14, } 1971 \\
\text { Mar. 16, } 1971 \\
\text { Mar. 29, } 1971 \\
\text { Mar. 30, } 1971 \\
\text { Mar. 31, } 1971 \\
\text { Apr. 12, } 1971 \\
\text { Apr. 13, } 1971 \\
\text { June 2, } 1971 \\
\text { Nov. 2, } 1971 \\
\text { Apr. 18, } 1973\end{array}$ & $\begin{array}{r}0.053 \\
.018 \\
.027 \\
.014 \\
.016 \\
.234 \\
.087 \\
.004 \\
.069 \\
. . .-.\end{array}$ & $\begin{array}{l}850 \\
420 \\
620 \\
495 \\
400 \\
450 \\
350 \\
650 \\
180 \\
820\end{array}$ \\
\hline $\begin{array}{l}\text { Mar. } 7,1972 \\
\text { Mar. 11, } 1972 \\
\text { Mar. 1, } 1973 \\
\text { Aug. 23, } 1973\end{array}$ & $\begin{array}{c}\text { Nakoma Road Storm Sewer } \\
.183 \\
.509 \\
.430 \\
.\end{array}$ & $\begin{array}{r}5,000 \\
800 \\
480 \\
115\end{array}$ \\
\hline $\begin{array}{l}\text { Mar. } 7,1972 \\
\text { Mar. 11, } 1972 \\
\text { Apr. 21, } 1972 \\
\text { Aug. 23, } 1973\end{array}$ & $\begin{array}{c}\text { Glenway Street Storm Sewer } \\
.067 \\
.150 \\
.342 \\
-.--\end{array}$ & $\begin{array}{r}3,300 \\
1,000 \\
80 \\
96\end{array}$ \\
\hline
\end{tabular}

Springs Dn-9 sp and Dn-6 sp discharge water with a relatively high chloride concentration at times. The chloride probably is derived from infiltration of water containing road salt.

Water discharged to the southwest end of the lake by upward percolation probably is similar to that discharged by the flowing well at the Nakoma Golf Course (Dn-1005). This is a calcium magnesium bicarbonate water similar to that discharged by the springs (table 9). 
Table 9.--Chemical analyses of samples of water from springs and a wel1.

[Analyses in milligrams per litre except specific conductance and $\mathrm{pH}$, in standard units.]

\begin{tabular}{|c|c|c|c|c|c|}
\hline & 证 & 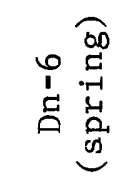 & ô & 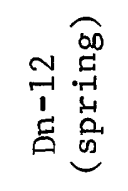 & 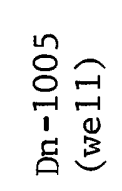 \\
\hline $\begin{array}{l}\text { Date collected } \\
\qquad(1973)\end{array}$ & $4-4$ & $4-4$ & $4-18$ & $4-18$ & $4-4$ \\
\hline Calcium (Ca) & 77 & 97 & 130 & 90 & 86 \\
\hline Magnesium (Mg) & 35 & 40 & 64 & 41 & 38 \\
\hline Sodium (Na) & 4.7 & 30 & 41 & 5.0 & 5.0 \\
\hline Potassium (K) & 1.1 & 1.5 & 3.5 & .8 & 1.7 \\
\hline Bicarbonate $\left(\mathrm{HCO}_{3}\right)$ & 350 & 386 & 442 & 388 & 384 \\
\hline Carbonate $\left(\mathrm{CO}_{3}\right)$ & 0 & 0 & 0 & 0 & 0 \\
\hline Sulfate $\left(\mathrm{SO}_{4}\right)$ & 26 & 38 & 81 & 45 & 35 \\
\hline Chloride (C1) & 9.3 & 69 & 140 & 14 & 12 \\
\hline Fluoride (F) & .1 & .1 & .2 & .4 & .1 \\
\hline Nitrate $\left(\mathrm{NO}_{3}\right)$ & 13 & 14 & 16 & 3.8 & 8.3 \\
\hline Dissolved solids & 341 & 506 & 780 & 413 & 376 \\
\hline \multirow{2}{*}{$\begin{array}{l}\mathrm{CaCO}_{3} \\
\text { Noncarbonate }\end{array}$} & 340 & 408 & 590 & 390 & 370 \\
\hline & 49 & 92 & 220 & 74 & 57 \\
\hline Specific conductance & 594 & 853 & 1,200 & 665 & 652 \\
\hline $\mathrm{pH}$ & 7.8 & 7.3 & 7.4 & 7.6 & 7.5 \\
\hline
\end{tabular}

Lake Water

Water in Lake Wingra, also of the calcium magnesium bicarbonate type, is lower in dissolved solids (as indicated by specific conductance) than the ground water entering the lake (tables 7 and 9). Kluesener (1972, p. 187-188) lists analyses of 31 samples of water collected from the central part of the lake at a depth of $1 \mathrm{~m}(3.3 \mathrm{ft})$. The samples were collected about twice a month from January 1970 through April 1971. Specific conductance of 30 of these samples ranged from 340 to 550 micromhos and averaged 430 micromhos; calcium $\left(\mathrm{Ca}^{+}\right)$concentration of 23 of the samples ranged from 21 to $47 \mathrm{mg} / 1$ (milligrams per litre) and averaged $34 \mathrm{mg} / 1$. A chemical analysis of a sample 
of water from the Lake Wingra outlet (Murphy Creek) listed in table 7 has a relatively high sodium chloride concentration, probably attributable to runoff affected by road salt.

\section{WATER BUDGET FOR LAKE WINGRA}

A preceding section on the hydrology of the Lake Wingra basin applied to the basin as a whole: the following discussion is concerned with the water budget of one part of the basin--the lake itself. A quantity of water within the basin may be expressed as a water depth on either the entire basin or as a water depth on only the lake. For example, surface-water discharge at the lake outlet in 1972 is equivalent to about 2,380 mm (93.5 in) on the lake surface (table 10) or $210 \mathrm{~mm}$ (8.3 in) on the entire basin (table 6).

Water enters Lake Wingra as precipitation on the lake surface, surface runoff, and ground-water inflow; water leaves the lake as water vapor, surface. runoff at the lake outlet, and ground-water outflow. The altitude of the lake surface rises and falls with variations in the amount of inflow and outflow. A monthly summary of measured and estimated increments of inflow and outflow from January 1972 through May 1973 is included in table 10. All quantities in the table and in the following discussion are expressed as millimetres on the lake surface.

This study did not include changes in soil moisture and does not include these changes in the water budget.

\section{Precipitation}

Precipitation was computed as the average of at least five of the seven rain gages in the Lake Wingra area (numerous difficulties prevented the daily use of all seven). Winter snows on the lake displaces its own weight because of the elasticity of the ice. Consequently, lake levels recorded at the lake gage respond to increments of precipitation in winter as well as in summer. Some discrepancies in the effects of winter precipitation may occur because of snow blowing onto or off the lake. Precipitation in the calendar year 1972 totaled $763 \mathrm{~mm}$ (30.1 in) on the lake surface. In the year ending May 31, 1973, precipitation was $1,142 \mathrm{~mm}$ (44.96 in). In the 17-month period ending May 31, 1973, precipitation totaled 1,326 mm (52.20 in).

\section{Surface Runoff}

About three-fourths of the $14.3-\mathrm{km}^{2}\left(5.5-\mathrm{mi}^{2}\right)$ land area draining into Lake Wingra is urban (streets and roads, parking lots, houses, lawns, golf courses, cemeteries, and parks); the remaining $3.9 \mathrm{~km}^{2}\left(1.5 \mathrm{mi}^{2}\right)$ is part of the University of Wisconsin Arboretum. Runoff from the urban area is flashy, rising to a peak during or shortly after heavy rains or snowmelt and declining to nothing during rainless periods. Surface runoff from the arboretum area is relatively sma11. Surface runoff in five storm sewers and in Marshland Creek was measured continuously at six gaging stations (table 3 ). These 
gaging stations measure runoff from $10.85 \mathrm{~km}^{2}\left(4.19 \mathrm{mi}^{2}\right)$. On the basis of topography and relative amounts of paved and unpaved areas, surface runoff from the ungaged $3.44 \mathrm{~km}^{2}\left(1.33 \mathrm{mi}^{2}\right)$ was estimated to be about 0.3 of the discharge of the Nakoma Road sewer. Measured and estimated surface runoff in calendar year 1972 was equivalent to $1,112 \mathrm{~mm}(43.8 \mathrm{in})$ on the lake surface. In the year ending May 31, 1973, surface runoff was equivalent to $1,663 \mathrm{~mm}$ (65.5 in). In the 17 -month period ending May 31, 1973, surface runoff was equivalent to $2,262 \mathrm{~mm}$ (89.1 in).

Surface runoff is the most variable component of inflow to Lake Wingra. The maximum monthly runoff, $362 \mathrm{~mm}$ (14.3 in) for the period January 1, 1972, through May 31, 1973, was more than 100 times the minimum monthly runoff of $3 \mathrm{~mm}$ (0.13 in).

\section{Ground-Water Inflow}

Ground water enters Lake Wingra by discharge of springs and by seepage through the sediments near the lake margin. Ground-water discharge has been neasured at eight springs (table 4 and p1. 1). It has been measured at least nonthly at three springs--Dn-5, 8 , and $6 \mathrm{sp}$. Occasional measurements of discharge have been made at four other springs--Dn-12, 13, 10, and $9 \mathrm{sp}$. A few measurements also have been made of ground-water discharge in lower Marshland Creek and Nakoma Creek, a small stream draining spring Dn-8 sp and Nakoma Golf Course. Another spring near spring Dn-6 sp has not been measured, but discharge is estimated to be one-tenth that of spring Dn-6 sp.

Measured and estimated ground-water discharges to springs and streams are summarized in table 10. In 1972 measured and estimated ground-water discharge to these springs and streams was equivalent to $1,315 \mathrm{~mm}$ (51.76 in) on the lake surface. In the year ending May 31, 1973, ground-water discharge was $1,313 \mathrm{~mm}$ ( $51.70 \mathrm{in})$. In the 17 months ending May 31, 1973, discharge ras $1,904 \mathrm{~mm}$ (74.98 in).

Ground-water discharge is much less variable than surface runoff. The naximum monthly ground-water discharge for the period January 1, 1972, through 'lay 31,1973 , (140 mm or $5.5 \mathrm{in}$ ) was only 1.6 times that of the minimum monthly discharge (860 $\mathrm{mm}$ or $2.6 \mathrm{in}$ ).

In addition to the visible discharge of springs and seeps, an inflow of rround water occurs by upward percolation to the marsh southwest of the lake and probably through bottom sediments in the southwestern part of the lake itself. Differences in water levels averaging about $2.6 \mathrm{~m}(8.5 \mathrm{ft})$ in adjacent wells (both in the upper aquifer) at the Nakoma Golf Course indicate $a$ potential for upward movement of ground water. The deeper well (Dn-1005), screened about $14 \mathrm{~m}(45.9 \mathrm{ft})$ below lake level, has water levels averaging about $3.4 \mathrm{~m}$ (11 ft) above lake level. The shallower well (Dn-1004), screened about $3 \mathrm{~m}(9.8 \mathrm{ft})$ below lake level, has water levels averaging about $0.8 \mathrm{~m}$ $(2.5 \mathrm{ft})$ above lake level. 
Table 10.--Monthly inflow and outflow and lake-stage changes for January 1972

[Al1 figures in

\begin{tabular}{|c|c|c|c|c|}
\hline & \multicolumn{4}{|c|}{ Inflow } \\
\hline & Precipitation & $\begin{array}{l}\text { Surface } \\
\text { runoff } 1 /\end{array}$ & Springs $2 /$ & Inflow \\
\hline \multicolumn{5}{|l|}{1972} \\
\hline January & 7 & 3 & 116 & 126 \\
\hline February & 7 & 44 & 104 & 155 \\
\hline March & 43 & 362 & 123 & 528 \\
\hline April & 57 & 122 & 131 & 310 \\
\hline May & 70 & 68 & 117 & 255 \\
\hline June & 26 & 5 & 92 & 123 \\
\hline July & 87 & 30 & 86 & 203 \\
\hline August & 194 & 194 & 108 & 496 \\
\hline September & 113 & 141 & 125 & 379 \\
\hline October & 82 & 75 & 107 & 264 \\
\hline November & 26 & 15 & 102 & 143 \\
\hline December & 51 & 53 & 104 & 208 \\
\hline \multicolumn{5}{|l|}{1973} \\
\hline January & 39 & 133 & 109 & 280 \\
\hline February & 41 & 156 & 95 & 292 \\
\hline March & 129 & 334 & 116 & 580 \\
\hline April & 194 & 264 & 129 & 588 \\
\hline May & 160 & 263 & 140 & 563 \\
\hline
\end{tabular}

1/About 75 percent of the drainage area was measured; 25 percent was estimated.

$\underline{2}$ Measured and estimated.

3/ Computed from EVAP program of Lake Wingra study office. 
Lake Wingra (exclusive of ground-water flow through lake bottom), through May 1973.

millimetres on lake surface]

\begin{tabular}{|c|c|c|c|c|c|c|}
\hline & Outflow & & & Lake- & tage change & \\
\hline $\begin{array}{l}\text { Evapor- } \\
\text { ation } \underline{3} /\end{array}$ & $\begin{array}{l}\text { Discharge at } \\
\text { lake outlet }\end{array}$ & Outflow & $\begin{array}{l}\text { Computed } \\
\text { in lake }\end{array}$ & $\begin{array}{l}\text { change } \\
\text { stage }\end{array}$ & $\begin{array}{l}\text { Actual } \\
\text { change at } \\
\text { gage }\end{array}$ & $\begin{array}{c}\text { Difference } \\
\text { computed } \\
\text { minus } \\
\text { actual }\end{array}$ \\
\hline 9 & 155 & 164 & -38 & & -21 & -17 \\
\hline 12 & 96 & 108 & 47 & & -15 & 62 \\
\hline 36 & 436 & 472 & 56 & & 46 & 10 \\
\hline 54 & 362 & 416 & -106 & & -6 & -100 \\
\hline 108 & 267 & 375 & -120 & & -76 & -44 \\
\hline 129 & 28 & 157 & -34 & & -61 & 27 \\
\hline 112 & 28 & 140 & 63 & & 3 & 60 \\
\hline 90 & 272 & 362 & 134 & & 149 & -15 \\
\hline 52 & 280 & 332 & 47 & & -18 & 65 \\
\hline 33 & 205 & 238 & 26 & & -25 & 51 \\
\hline 11 & 145 & 156 & -13 & & -37 & 24 \\
\hline 4 & 104 & 108 & 100 & & 61 & 39 \\
\hline 11 & 316 & 328 & -48 & & -18 & -30 \\
\hline 14 & 304 & 318 & -25 & & -12 & -13 \\
\hline 37 & 644 & 680 & -101 & & 6 & -107 \\
\hline 53 & 568 & 621 & -34 & & 61 & -95 \\
\hline 76 & 590 & 666 & -102 & & -12 & -90 \\
\hline
\end{tabular}


The quantity of water moving to and from the lake depends on the hydraulic conductivity of the sediments under the lake, the hydraulic gradient between deeper and shallower sediments, and the area over which these differences apply.

The hydraulic conductivity of the sediments underlying the lake is estimated to be $0.02 \mathrm{~m} / \mathrm{d}(0.07 \mathrm{ft} / \mathrm{d})$. This estimate is based on laboratory determinations of five samples of lake-bed materials. Although only about $1 \mathrm{~m}$ (3.3 ft) of bottom sediments was sampled at each site, and the samples were considerably compressed in coring, the reported hydraulic conductivities appear reasonable for the materials underlying the lake. The hydraulic gradient between the deeper and shallower sediments at the southwest end of the lake is about 0.24. The estimated upward percolation in this area is 0.02 (hydraulic conductivity) $\times 0.24$ (hydraulic gradient) = $0.0048\left(\mathrm{~m}^{3} / \mathrm{d}\right) / \mathrm{m}^{2}\left[0.016\left(\mathrm{ft}^{3} / \mathrm{d}\right) / \mathrm{ft}^{2}\right]$.

Water levels in observation wells suggest that upward percolation to the lake and marsh may occur in an area of $0.26 \mathrm{~km}^{2}\left(0.10 \mathrm{mi}^{2}\right)$. Accordingly, other than springs and seeps listed in table 2, ground-water inflow to the lake is estimated to be $0.0001 \mathrm{~m} / \mathrm{d}(0.0003 \mathrm{ft} / \mathrm{d})$ or $0.36 \mathrm{~m} / \mathrm{yr}(1.2 \mathrm{ft} / \mathrm{yr})$ over the entire lake surface. The rate of ground-water inflow no doubt varies as water levels fluctuate in response to recharge and pumping city wells, but available data are insufficient to determine the magnitude of these variations. Because the data supporting the above estimates are so meager and monthly variations are unknown, this increment of ground-water inflow is not included in the monthly water budget presented in table 10, but it is included in the annual budget presented under "Water Budget--Summary".

\section{Evaporation}

Evaporation from the lake and lagoons was estimated by D. D. Huff (written commun., 1973) from a computer program utilizing precipitation, air temperature, dew-point temperature, wind velocity, and solar radiation. Evaporation is greatest in midsummer and least in midwinter. Evaporation is the only item in the water budget that is not directly related to the amount of precipitation. During dry years evaporation from Lake Wingra may be nearly as great as precipitation; in wet years precipitation may be 80 percent greater than evaporation. Evaporation in calendar year 1972 was estimated to total $650 \mathrm{~mm}$ (25.6 in). In the year ending May 31, 1973, evaporation was $622 \mathrm{~mm}$ (24.5 in). In the 17 months ending May 31, 1973, evaporation was $841 \mathrm{~mm}$ (33.1 in).

Not included in these estimates is evaporation and transpiration from the marsh area $\left(0.41 \mathrm{~km}^{2}\right.$ or $\left.0.16 \mathrm{mi}^{2}\right)$ at the southwest end of the lake. On an annual basis evapotranspiration may be offset by precipitation on this area, but evapotranspiration may greatly exceed precipitation during the summer.

A reverse process to evaporation, condensation of water vapor on the late surface, also may occur when the lake is colder than the air. No estimate has been made of the amount of this condensation, but it would be expected to be 
relatively large in early spring when the water temperatures generally are lower than air temperatures.

\section{Lake Wingra Outlet}

Outflow of Lake Wingra to Murphy Creek, measured continuously at the outlet gaging station, probably is the most accurate of al1 increments of the water budget. Outflow varies with lake stage and genera11y is greatest during the spring snowmelt. Discharge at the lake outlet in calendar year 1972 was equivalent to $2,378 \mathrm{~mm}$ (93.63 in) on the lake surface. In the year ending May 31, 1973, discharge at the Lake Wingra outlet was 3,484 mm (137.2 in). In the 17-month period ending May 31, 1973, discharge was equivalent to $4,800 \mathrm{~mm}$ ( $189.0 \mathrm{in})$.

Errors in measurement of discharge could occur if floating debris were to become temporarily lodged in the V-notch control at the gaging station, but no evidence of such debris has been detected. Another possible source of error in lake-outlet discharge is a canal that bypasses the lake-outlet gage. This canal leads from the Vilas Park lagoon and, before September 1972, was occasiona11y used to flush out the lagoon in summer. No record was kept of the times the canal was opened, and the gate reportedly was opened at times by unauthorized personnel, so the timing and amount of water bypassing the gage are unknown.

\section{Ground-Water Outflow}

Water levels in observation wells suggest that downward leakage may occur $\mathrm{n}$ an area of about $1 \mathrm{~km}^{2}\left(0.4 \mathrm{mi}^{2}\right)$ at the east end of Lake Wingra. Two adjacent we1ls near the east edge of the lake (both in the upper aquifer), about $0.5 \mathrm{~km}(0.3 \mathrm{mi})$ south of the lake outlet, have a water-level differential of $1.4 \mathrm{~m}(4.6 \mathrm{ft})$. The deeper we11 (Dn-1001), screened $19 \mathrm{~m}$ (62 ft) below lake leve1, has water levels averaging $1.8 \mathrm{~m}(5.9 \mathrm{ft})$ below lake level. The shallower well (Dn-1000), screened $2.5 \mathrm{~m}(8.2 \mathrm{ft})$ below lake level, has water levels averaging $0.4 \mathrm{~m}$ ( $1.3 \mathrm{ft})$ below lake level. The estimated downward leakage at the east end of the lake is 0.02 (hydraulic conductivity) $\times 0.08$ (hydraulic gradient) $=0.0016\left(\mathrm{~m}^{3} / \mathrm{d}\right) / \mathrm{m}^{2}\left[0.0052\left(\mathrm{ft}^{3} / \mathrm{d}\right) / \mathrm{ft}^{2}\right]$. Estimated lownward leakage from the lake is equivalent to $0.0013 \mathrm{~m} / \mathrm{d}(0.0046 \mathrm{ft} / \mathrm{d})$ or $.47 \mathrm{~m} / \mathrm{yr}(1.5 \mathrm{ft} / \mathrm{yr})$ over the lake surface.

The rate of ground-water outflow varies as water levels in deep and hallow aquifers vary with fluctuations in recharge and pumpage. Water 1evels in the two observation we11s (Dn-1000 and Dn-1001) apparently are influenced sy the rate of pumping of city we11s; lower water levels generally correlate vith higher pumping rates. Fluctuations in the deeper well are greater than those in the shallower we11, and differences in water levels in the two we11s suggest a possible correlation with pumpage. Although records of water-level =luctuations in these two wells could be used to indicate changes in the rate ,f ground-water outflow in the vicinity of the we11s, water-leve1 fluctuations In shallow and deep aquifers in other parts of the lake are not recorded. Consequently, ground-water outflow has not been included in the monthly budget In table 10, but it is included in the annual budget presented under "Water "3udget--Summary". 
Measurements and estimates of gains and losses to and from Lake Jingra are in approximate balance on an annual basis. For calendar year 1972 the water budget for Lake Ningra is as follows:

\section{GAINS}

\section{Mi11imetres}

Precipitation on

lake surface $1 /$

763

Surface runoff 2 /

Springs $2 /$

Other ground-

water inflow

Tota1s
1,112

1,315

370

3,560

\section{LOSSES}

Millimetres

Evaporation from
lake surface

Discharge at Lake

Wingra out let1/

2,378

Ground-water
outflow-

470

3,498

1/ Measured

2/ Measured and estimated

$3 /$ Estimated

4/Calculated

The leve1 of Lake Wingra was the same at the end of the year as it was in the beginning, so the measured and estimated additions exceeded the measured and estimated withdrawals by $62 \mathrm{~mm}(2.5 \mathrm{in})$. This is less than 2 percent of the total annual budget and is much less than the probable error of any measured or estimated item in the budget.

For the 12-month period ending May 31, 1973, the water budget for Lake Wingra is as follows:

\section{GAINS}

\section{LOSSES}

\section{Mil1imetres}

Precipitation on
lake surface $1 /$

Surface runoff $\underline{2}$ /

Springs $2 /$

Other ground-

water inflow ${ }^{3 /}$

Tota1s
1,142

1,663

1,313

370

4,488
Evaporation from
lake surface 4

Discharge at Lake Wingra outlet I/

Ground-water outflow 3 /
Millimetres

3,484

470

4,576

1/ Measured

2/ Measured and estimated

3/Estimated

4/ Calculated 
The leve1 of Lake Wingra rose $97 \mathrm{~mm}$ (3.8 in) during this 12-month period, so the measured and estimated withdrawals exceeded the measured and estimated additions by about $185 \mathrm{~mm}(7.3 \mathrm{in})$. This is about 4 percent of the total annual budget.

For the 17-month period ending May 31, 1973, the water budget for Lake Wingra is as follows:

\section{GAINS}

Mi11imetres

\section{Precipitation on}

lake surface 1/

Surface runoff $\underline{2}$

Springs 2 /

Other ground-

water inflow 3 /

Totals

$$
\begin{array}{r}
1,326 \\
2,262 \\
1,904 \\
530 \\
\hline 6,022
\end{array}
$$

\section{LOSSES}

Millimetres

$$
\begin{gathered}
\text { Evaporation from } \\
\text { lake surface } 4 /
\end{gathered}
$$

Discharge at Lake

Wingra outlet I/

4,800

Ground-water

670

6,311

$\underline{1} /$ Measured

$2 /$ Measured and estimated

$\underline{3} /$ Estimated

4/Calculated

The level of Lake Wingra rose $24 \mathrm{~mm}$ ( $0.96 \mathrm{in})$ during this 17 -month period, so the measured and estimated withdrawals exceeded the measured and estimated additions by $313 \mathrm{~mm}(12.3 \mathrm{in})$. This is about 5 percent of the total budget for the 17 -month period.

As indicated above, the measured and estimated gains approximately balanced the measured and estimated losses on an annual basis. However, the monthly budget (which does not include ground-water inflow and outflow to and from the lake other than visible springs) shows substantial discrepancy (table 10). During January 1, 1972 through May 31, 1973, these discrepancies ranged from $+64 \mathrm{~mm}$ ( $2.5 \mathrm{in})$ to $-107 \mathrm{~mm}(4.2 \mathrm{in})$. A negative discrepancy generally occurs when lake stages are high (high discharge), and a positive discrepancy is associated with low lake stages. In other words, when lake stage is high more discharge occurs than is measured at the lake outlet. When lake stage is low, there was more inflow and less outflow than was measured.

These discrepancies are largely the result of ungaged flow bypassing the lake outlet gage, ground-water inflow and outflow components that are not included in the monthly computations, seasonal variation of ice-or soilmoisture storage in the wetland area, and measurement inaccuracies inherent in the several other components of inflow and outflow. When lake stage is 
high (outlet discharge 1arge) some flow bypasses the outlet gage through the lagoons and a $0.76 \mathrm{~m}(30-\mathrm{in})$ storm sewer at the north side of the lake. (Measurements indicate that this flow could exceed $15 \mathrm{~mm}$ (0.6 in) per month or $180 \mathrm{~mm}$ (7 in) per year.) However, this flow was not gaged continuously but is estimated in the water budget. Data were insufficient to compute monthly variations of ground-water inflow (other than springs) and outflow, or to compute the effect of seasonal changes in ice storage or soil-moisture storage, so these elements probably contribute to the observed discrepancies. However, the budget on an annual basis is probably adequate for predictive purposes and could be much improved on a monthly basis if records of the flow bypassing the lake outlet gage were obtained. 


\section{SELECTED REFERENCES}

Cline, D. R., 1965, Geology and ground-water resources of Dane County, Wisconsin: U.S. Geol. Survey Water-Supply Paper 1779-U, 64 p.

Cullen, R. S., Jacques, J. E., and Huff, D. D., 1972, Lake Wingra drainage basin, sub-basin configuration: Univ. of Wisconsin, U.S. Internat. Biome Period, Lake Wingra Study map.

Dettman, E. H., and Huff, D. D., 1972, A lake water-balance model: Univ. of Wisconsin, Eastern Deciduous Forest Biome Memo. Rept. 72-126, 22 p.

Huff, D. D., Koonce, J. F., Ivarson, W. R., Weiler, P. R., Dettman, E. H., and Harris, R. F., 1973, Simulation of urban runoff, nutrient loading, and biotic response of a shallow eutrophic lake, in Middlebrooks, E. J., Falkenborg, D. H., and Maloney, T. E., eds., Modeling the eutrophication process: Utah Water Research Laboratory, Utah State University, Logan, p. $33-55$.

Juday, Chancey, 1914, Lakes of the Yahara basin, in The inland lakes of Wisconsin: Wisconsin Geol. and Nat. History Survey Bul1. 27, Sci. Ser. 9, p. 11-29.

Kluesener, J. W., 1972, Nutrient transport and transformation in Lake Wingra, Wisconsin: Univ. of Wisconsin, Eastern Deciduous Forest Biome Memo. Rept. 72-42, 180 p.

McLeod, R. S., 1975, A digita1-computer model for estimating drawdowns in the sandstone aquifer in Dane County, Wisconsin: Wisconsin Geol. and Nat. History Survey Inf. Circ. 28, $91 \mathrm{p}$.

Noland, W. E., 1951, The hydrography, fish and turtle population of Lake Wingra: Trans. Wisconsin Acad. Sci. Arts and Letters, v. 40, pt. 2, p. 5-58. 
